Sains Malaysiana 50(2)(2021): 537-547

http://dx.doi.org/10.17576/jsm-2021-5002-24

\title{
Acoustic Properties of Lightweight Foamed Concrete with Eggshell Waste as Partial Cement Replacement Material
}

(Sifat Akustik Konkrit Berbusa Ringan dengan Sisa Kulit Telur sebagai Bahan Penggantian Simen Separa)

\author{
Lim Siong Kang*, Foo Kar Poh, Lee Foo Wei, Tiong Hock Yong, Lee Yee Ling, Lim Jee Hock \& King \\ YEONG JIN
}

\begin{abstract}
Nowadays, almost every industry needs to undergo green and sustainable industrial revolution due to pollutions like waste dumping and noise that deteriorating the environment. Therefore, feasibility study on application of eggshell waste as partial cement replacement in lightweight foamed concrete was conducted by aiming to solve environmental and acoustical issues, i.e. reduce eggshell waste and improve acoustic properties. In this study, compressive strength and acoustic properties of $1300 \mathrm{~kg} \mathrm{~m}^{-3}$ lightweight foamed concrete with and without $5 \%$ eggshell powder as partial cement replacement material were tested. Optimal water to cement ratio of 0.6 was obtained for acoustic properties test by comparing compressive strength result. The result shows that application eggshell powder has generally reduced 7 days compressive strength but improved 28 days compressive strength, and either improve or maintain acoustics properties, in which lightweight foamed concrete that containing eggshell powder has improved noise reduction coefficient at testing ages of 7,28, and 90 days and improved sound transmission class at testing age of 56 and 90 days. Based on these results, $5 \%$ of eggshell powder is feasible to be incorporated into lightweight foamed concrete as partial cement replacement material for sound insulation and strength development purposes.
\end{abstract}

Keywords: Acoustic properties; eggshell waste; foamed concrete; performance index

\section{ABSTRAK}

Pada masa ini, hampir setiap industri perlu melalui revolusi industri hijau dan lestari kerana pencemaran seperti pembuangan sampah dan hingar yang merosakkan persekitaran. Oleh itu, kajian kebolehlaksanaan penggunaan sisa kulit telur sebagai penggantian simen separa dalam konkrit berbusa ringan telah dijalankan bertujuan untuk menyelesaikan masalah persekitaran dan akustik, iaitu mengurangkan sisa kulit telur dan meningkatkan sifat akustik. Dalam kajian ini, kekuatan mampatan dan sifat akustik $1300 \mathrm{~kg} \mathrm{~m}^{-3}$ konkrit berbusa ringan dengan dan tanpa 5\% serbuk kulit telur sebagai bahan pengganti simen separa diuji. Nisbah air dan simen optimum 0.6 diperoleh untuk ujian sifat akustik dengan membandingkan hasil kekuatan mampatan. Hasilnya menunjukkan bahawa penggunaan serbuk kulit telur secara amnya telah mengurangkan kekuatan mampatan 7 hari tetapi meningkatkan kekuatan mampatan selama 28 hari, sama ada memperbaiki atau mengekalkan sifat akustik dengan konkrit berbusa ringan yang mengandungi serbuk kulit telur telah meningkatkan pekali pengurangan hingar pada usia ujian 7, 28 dan 90 hari serta peningkatan kelas transmisi suara pada usia ujian 56 dan 90 hari. Berdasarkan hasilnya, 5\% serbuk kulit telur layak untuk dimasukkan ke dalam konkrit berbusa ringan sebagai bahan pengganti semen separa untuk tujuan penebat dan pengembangan kekuatan.

Kata kunci: Indeks prestasi; konkrit berbuih; sifat akustik; sisa kulit telur

\section{INTRODUCTION}

After a long-term period, usage of Portland cement, apart from the introduction of chemical admixtures, there is a trend by reusing industrial and agricultural wastes (Shafigh et al. 2014). The cement used in casting of concrete is partially replaced by the both wastes that are also pozzolanic materials such as fly ash, slag (Tiong et al. 2017; Zhao et al. 2015) silica fume, rice husk ash (Mehta 1977), palm oil fuel ash (Lim et al. 2013; Tangchirapat et al. 2007), sugar cane bagasse ash, sawdust or wood waste ash (Udoeyo \& Dashibil 2002), bamboo leaf ash, and corn cob ash (Aprianti 2017). This is a notable huge 
change where industrial wastes are now famous and given attentions for their reuses in triggering pozzolanic reaction with portlandite, $\mathrm{Ca}(\mathrm{OH})_{2}$, forming the wanted and required calcium silicate hydrate (C-S-H) gels which are responsible for the strength of concrete. Pozzolanic materials usually partially replace cement content in the range of 5 to $20 \%$ with benefits of reducing $\mathrm{CO}_{2}$ emission and enhancing long-term mechanical strength and durability (Juenger \& Siddique 2015). Pozzolanic materials are possible to be used in lightweight concrete as well by partial of cement.

Different from people living in old days, nowadays, buyers who are seeking and buying their accommodations will not only just aim for shelters that provide safety and protections from sunlight, rain and weathering, but they will also take into considerations of energy saving, thermal and acoustic comfort, traffic accessibility and mobility, and sustainable building materials and construction before they make any decision. Hence, concrete with better qualities and properties must be expected to cater for all the expectations, requirements, and needs as normal concrete cast and practised by developers may not be able to meet the mentioned criteria. Among the various ranges of concrete of heavyweight concrete, normal weight concrete, and lightweight concrete, lightweight concrete with sufficient strength now comes into priority to fulfil the energy saving as well as thermal and acoustic comfort criteria. This is mainly because lightweight concrete has the desired porosity. The voids especially microscopic air voids inside lightweight concrete are weak in heat gain and they could be good sound insulators as well because sound wave energies might be trapped inside the voids or empty spaces like air pockets.

There are some other advantages of using lightweight concrete. Lightweight concrete is preferred due to its low dead load. With the significant reduction of dead load, the uses of smaller cross-sections and sizes of load bearing structures and foundations can be achieved (Neville 2011). The lower dead load of lightweight concrete will result in better and safer design for earthquake as earthquake load is proportional to weight of building (Tito et al. 2010). The low load specification being characterised by lightweight concrete will lead to benefit of cost saving due to reduction in casting cost and transportation fee. Therefore, lightweight concrete is gaining its popularity and hence there is a shifting trend from use of normal weight concrete to lightweight concrete as non-load bearing structures like wall panels.

Sound is a physical sensation produced by pressure variations in air. To produce sound, there must be a source of vibrations like loudspeaker. Sound waves produced also require medium to propagate further, be it air, liquid, or solid. This deduces that sound waves cannot pass through void medium. Sound is transmitted into building in the form of airborne sound or impact sound. Airborne sound is the sound produced by vibrating source and it travels through air as its medium of propagation. Impact sound is also known as structure-borne sound. It is the sound produced when a source sets building components into vibrations by impact. The typical sound source examples are music, speech, and traffic noise for airborne sound; and footsteps, vibrating machine, and slammed doors for impact sound (Virdi 2012).

When noise level is very high, it becomes a hazard and people suffering from it are always facing some health problems. For instance, at the noise level above 60 $\mathrm{dB}$ and the frequency range of 2000 to $5000 \mathrm{~Hz}$, humans would feel discomfort and annoying to the eardrum (Lu et al. 2000). As human population is exploding at shocking rate in this globalization era, acoustic comfort criterion is a must owing to the massive construction developments and frequent travel rate of vehicle and aircrafts. Conventional concrete has hard and smooth surface to reflect $95 \%$ of the sound and minimise the sound transmission, however, it has poor sound absorption of only 2 to $5 \%$ which resulted to sound echoes circulated within the enclosed source space (Egab et al. 2014). As reviewed by Ramamurthy et al. (2009), foamed concrete is less effective as compared to dense concrete on transmission loss as transmission loss increased when unit mass of partition increased regardless type of material used, and this is sometimes referred to as 'mass law' (Neville 2011); however dense concrete tends to deflect sound, foam concrete absorbs it, and hence the foamed concrete has higher sound absorption capacity.

Eggshell might contain up to $99 \%$ of calcium carbonate (Tiong et al. 2020). Calcium carbonate will act as inert filler to decrease porosity and increase strength of concrete (Matschei et al. 2007). Calcium carbonate in sediments can also reduce the sound velocity (Garlan et al. 2015). However, eggshell waste is costly to dispose, and inappropriate disposal of it is causing pollutions and unpleasant condition such as attracting rats and other vermin due to its mass amount and its protein-rich membrane (Sonenklar 1999).

The main scope of this study was assessing the feasibility of using 5\% of eggshell powder as partial cement replacement material cum filler to enhance the sound insulation of lightweight foamed concrete (LFC) with fresh and hardened densities to be controlled at 1300 $\pm 50 \mathrm{~kg} \mathrm{~m}^{-3}$.

\section{MATERIALS AND METHODS}

EGGSHELL POWDER PREPARATION

Eggshell powders were prepared with reference from Tiong et al. (2020). They were collected from a local egg 
supplier, in Malaysia. They were cleaned of unwanted wastes and crushed into smaller pieces before they were sun-dried. Sun-dried eggshell pieces were later blended into finer pieces by using blender. The main objective of wet blending the eggshell pieces is to separate eggshell membranes from the mixture apart from obtaining the finer eggshell pieces. Eggshell membranes are unwanted as they are of organic compounds, mostly composed of amino acids, which are decayable. The blended fine eggshell pieces were collected in a plastic bowl. Water with floating eggshell membranes and bubbles was poured off. The remaining fine eggshell pieces were rinsed with water for a few times to clean unwanted eggshell membranes. They were cleaned until clean, visible water was observed. The cleaned fine eggshell pieces were collected in a pan with water being almost removed. The eggshells were oven-dried in an oven for $24 \mathrm{~h}$. The oven-dried fine eggshell pieces were then ground by a grinder to obtain eggshell powders. Eggshell powders were sieved through $63 \mu \mathrm{m}$ sieve to get approximately same sizing as cement clinker. The sieved eggshell powders were stored in air tight container.

\section{COMPRESSIVE STRENGTH TEST}

One day prior to respective testing ages of 7 and 28 days reached, $100 \mathrm{~mm}$ LFC cubical samples were removed from water curing tank and oven-dried for 1 day at 105 ${ }^{\circ} \mathrm{C}$, and then tested for their compressive strength at corresponding testing ages. The test was carried out by referring to BS EN 12390-3 at loading rate of $2 \mathrm{kN} \mathrm{s}^{-1}$.

\section{TRIAL MIX}

Given well prepared raw materials of local branded 42.5N CEM I, i.e. Ordinary Portland Cement (OPC) and fine sand (100\% passing through $0.6 \mathrm{~mm})$, trial mixes were conducted to determine the optimal water to cement ratio $(\mathrm{w} / \mathrm{c}$ ) for both $\mathrm{LFC}$ batches of control mix and 5.0\% eggshell replacement mix, in which several $\mathrm{w} / \mathrm{c}$ namely $0.52,0.56,0.6,0.64$, and 0.68 were attempted. Mix proportions of trial mix are provided as in Table 1 while achieved fresh and hardened densities and compressive strength are shown in Table 2. Optimal w/c was found at 0.6 , hence LFC-CTR-0.6 and LFC-ES5.0-0.6 were selected for acoustics properties analysis.

TABLE 1. Mix proportion of trial mix

\begin{tabular}{|c|c|c|c|c|c|c|}
\hline \multirow{2}{*}{ Specimen } & \multirow{2}{*}{$\mathrm{w} / \mathrm{c}$} & \multicolumn{5}{|c|}{ Material $\left(\mathrm{kg} \mathrm{m}^{-3}\right)$} \\
\hline & & Cement & Eggshell* & Sand & Water & Foam** \\
\hline LFC-CTR-0.52 & 0.52 & 671 & 0 & 671 & 349 & 27 \\
\hline LFC-CTR- 0.56 & 0.56 & 660 & 0 & 660 & 370 & 26 \\
\hline LFC-CTR-0.60 & 0.6 & 650 & 0 & 650 & 390 & 26 \\
\hline LFC-CTR-0.64 & 0.64 & 640 & 0 & 640 & 410 & 26 \\
\hline LFC-CTR-0.68 & 0.68 & 631 & 0 & 631 & 429 & 25 \\
\hline LFC-ES5.0-0.52 & 0.52 & 637 & 34 & 671 & 349 & 27 \\
\hline LFC-ES5.0-0.56 & 0.56 & 627 & 33 & 660 & 370 & 26 \\
\hline LFC-ES5.0-0.60 & 0.6 & 618 & 33 & 650 & 390 & 26 \\
\hline LFC-ES5.0-0.64 & 0.64 & 608 & 32 & 640 & 410 & 26 \\
\hline LFC-ES5.0-0.68 & 0.68 & 599 & 32 & 631 & 429 & 25 \\
\hline
\end{tabular}

* Eggshell is introduced by partially replacing cement content by $5.0 \%$ of cement weight/ density. ** Foam is dosed based on maximum $2 \%$ of dry mix density 
TABLE 2. Fresh and hardened densities and compressive strength of trial mix

\begin{tabular}{|c|c|c|c|c|c|c|}
\hline \multirow[t]{2}{*}{ Specimen } & \multicolumn{2}{|c|}{$\begin{array}{l}\text { Fresh density } \\
\qquad\left(\mathrm{kg} \mathrm{m}^{-3}\right)\end{array}$} & \multicolumn{2}{|c|}{ Hardened density $\left(\mathrm{kg} \mathrm{m}^{-3}\right)$} & \multicolumn{2}{|c|}{ Compressive strength (MPa) } \\
\hline & 7-day & 28-day & 7-day & 28-day & 7-day & 28-day \\
\hline LFC-CTR- 0.52 & 1281 & 1281 & 1262 & 1269 & 3.59 & 4.13 \\
\hline LFC-CTR-0.56 & 1340 & 1339 & 1312 & 1296 & 4.23 & 4.76 \\
\hline LFC-CTR-0.60 & 1328 & 1328 & 1304 & 1306 & 4.75 & 5.10 \\
\hline LFC-CTR-0.64 & 1320 & 1298 & 1302 & 1281 & 4.43 & 4.69 \\
\hline LFC-CTR-0.68 & 1327 & 1327 & 1314 & 1344 & 4.38 & 4.84 \\
\hline LFC-ES5.0-0.52 & 1283 & 1283 & 1272 & 1292 & 2.48 & 4.10 \\
\hline LFC-ES5.0-0.56 & 1302 & 1302 & 1284 & 1267 & 2.71 & 4.55 \\
\hline LFC-ES5.0-0.60 & 1340 & 1340 & 1330 & 1314 & 4.05 & 6.70 \\
\hline LFC-ES5.0-0.64 & 1326 & 1326 & 1274 & 1259 & 2.57 & 5.04 \\
\hline LFC-ES5.0-0.68 & 1299 & 1299 & 1293 & 1282 & 2.52 & 4.17 \\
\hline
\end{tabular}

LIGHTWEIGHT FOAMED CONCRETE CYLINDRICAL SAMPLES CASTING

After trial mixes, LFC samples were cast based on determined optimal water to cement ratio of 0.6 . They were prepared for 7, 28, 56 and 90 days with three (3) samples for each testing ages. The casting is as shown in Figure 1.
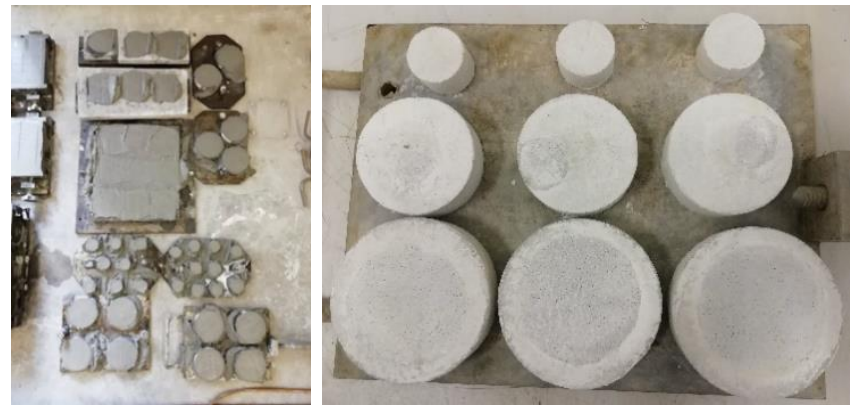

FIGURE 1. (a) Cast cylindrical samples (b) oven-dried cylindrical samples

\section{ACOUSTIC PROPERTIES TESTING}

When respective curing period reached, LFC cylindrical samples were tested for their acoustic parameters. The required equipment is impedance tube and the tests were performed as according to ISO 10534-2. The main parameters obtained in the tests are sound absorption and sound transmission loss. 


\section{RESULTS AND DISCUSSION}

\section{PERFORMANCE INDEX ANALYSIS}

Performance indexes of various mixes were computed based on the concept of compressive strengths of LFC cube samples per $1000 \mathrm{~kg} \mathrm{~m}^{-3}$ (Lim et al. 2013) so as to facilitate comparison and discussion purposes. The results are shown in Figure 2.

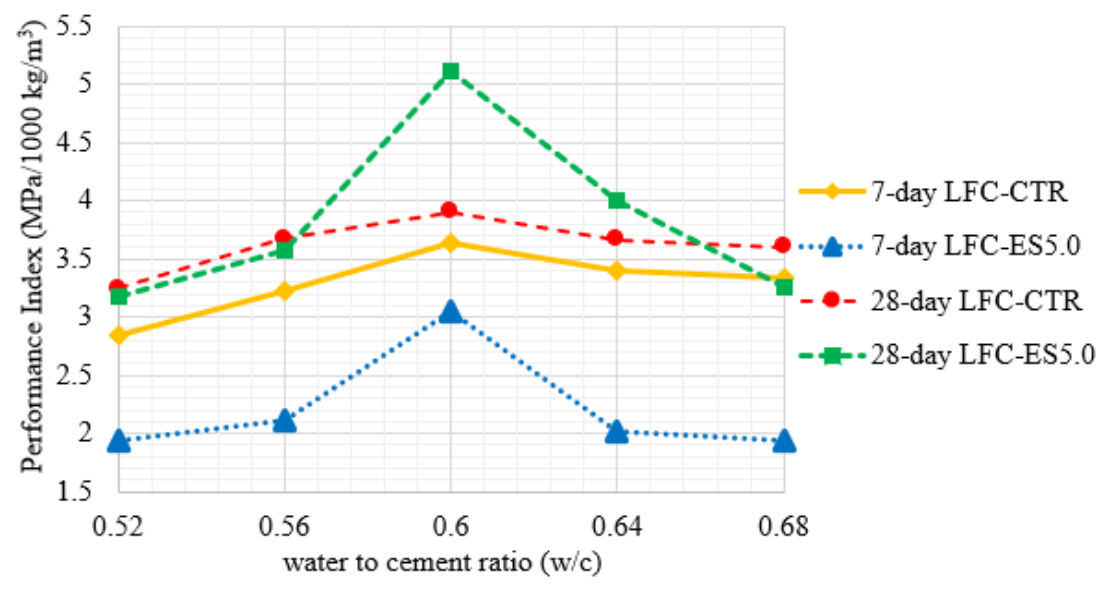

FIGURE 2. Performance index analysis chart

Referring to Figure 2, at the age of 7-day, LFC-CTR has generally higher performance indexes at all w/c than LFC-ES5.0. This could be inferenced that the tricalcium silicate $\left(\mathrm{C}_{3} \mathrm{~S}\right)$ and tricalcium aluminate $\left(\mathrm{C}_{3} \mathrm{~A}\right)$ constituents of LFC-CTR trigger early cement hydration process and yield higher early strength by utilising greater amount of water during the hydration process. For LFC-ES5.0, as its cement content is partially replaced by $5.0 \%$ eggshell, there are lesser $\mathrm{C}_{3} \mathrm{~S}$ and $\mathrm{C}_{3} \mathrm{~A}$ constituents to promote early cement strength development. Hence, it is utilising lesser amount of water for early cement hydration process and this eventually yields weaker early strength than its control.

At the age of 28-day, it is observable from Figure 2 that at optimal water to cement ratio of 0.60 , LFCES5.0 has higher performance index than its control. Meanwhile, for LFC-CTR, it has overall slowed down strength development as compared to its 7-day strength development, resulting a phenomenon that its performance indexes at all $\mathrm{w} / \mathrm{c}$ at age of 28 days are only a little higher than those at age of 7 days. On the other hand, LFC-ES5.0 has greater strength development in later age as its 28-day performance indexes surge up more effectively than that of 28-day LFC-CTR.

The surged-up strength development of LFCES5.0 might be because eggshell had act as inert filler to decrease porosity and increase strength (Matschei et al. 2007). It might also because the calcium carbonate from eggshell reacts with alumina phases of cement to produce monocarboaluminates which can enhance the strength (Ramezanianpour \& Hooton 2014). Besides, possible carbonation and calcite precipitation process over the curing period might also enhance the strength, in which free calcite $\left(\mathrm{CaCO}_{3}\right)$ from eggshell subjected to possible carbonation by carbon dioxide dissolved water to form calcium bicarbonate $\left(\mathrm{Ca}\left(\mathrm{HCO}_{3}\right)_{2}\right)$ that dissolved in pore water and thereafter precipitate to form better calcite structure in LFC and release carbon dioxide. There were various studies carried out on calcite precipitation to enhance the strength and sealing the crack of concrete, as example, Manzur et al. (2019) had studied on performance enhancement of brick aggregate concrete using microbiologically induced calcite precipitation.

In addition, it might also due to pozzolans existing and available in eggshell powder. Therefore, it can be understood that strength development of LFC-ES5.0 surges up in later stage and yields highest performance index at optimal water to cement ratio of 0.60 . The possible pozzolans available in eggshell powder might be $\mathrm{SiO}_{2}$ and $\mathrm{Al}_{2} \mathrm{O}_{3}$. It is supported by X-ray spectrometry results by Ayodeji et al. (2018) and Tchuente et al. (2019). Table 3 shows some major compounds in eggshell except calcite $\mathrm{CaCO}_{3}$ (Ayodeji et al. 2018; Tchuente et al. 2019; Tiong et al. 2020). 
TABLE 3. Oxide compounds of eggshell powder

\begin{tabular}{lccc}
\hline \multirow{2}{*}{ Oxides } & \multicolumn{3}{c}{ Eggshell constituent (\%) } \\
\cline { 2 - 4 } & Tchuente et al. 2019 & Ayodeji et al. 2018 & Tiong et al. 2020 \\
\hline $\mathrm{Na}_{2} \mathrm{O}$ & 0.136 & - & - \\
$\mathrm{MgO}$ & 0.855 & 0.531 & - \\
$\mathrm{Al}_{2} \mathrm{O}_{3}$ & 0.233 & 0.353 & 0.207 \\
$\mathrm{SiO}_{2}$ & 0.243 & 1.504 & - \\
$\mathrm{P}_{2} \mathrm{O}_{5}$ & 0.476 & 0.283 & - \\
$\mathrm{SO}_{3}$ & 0.206 & 0.559 & 0.467 \\
$\mathrm{~K}_{2} \mathrm{O}$ & 0.071 & 0.118 & 0.029 \\
$\mathrm{Fe}_{2} \mathrm{O}_{3}$ & - & - & 0.093 \\
\hline
\end{tabular}

\section{SOUND ABSORPTION}

The sound absorption coefficients are tabulated and shown as in Table 4 and Figure 3. They were measured through transfer function method by using BSWA VA-Lab4 software. Noise reduction coefficients (NRC) are also calculated as average of sound absorption coefficients at frequency of $250,500,1000$, and $2000 \mathrm{~Hz}$ (Neville 2011).

The results show that the noise reduction coefficient of the LFC decrease when curing periods increase. A similar phenomenon was observed on the sound absorption coefficient based on its third octave bands frequencies. This is possible as when curing periods increase, more cement hydrations or pozzolanic reactions will be carried out. This eventually produces more hydrated cement pastes that fill up empty spaces and voids in a sample. Hence, the sound absorption capability of both LFC batches reduces as there are lesser porous and void structures to absorb and trap sound wave energies.

TABLE 4. Sound absorption coefficients and noise reduction coefficient (NRC) of the lightweight foamed concrete batches (LFCCTR and LFC-ES5.0) at various ages

\begin{tabular}{lcccccccc}
\hline $\begin{array}{l}\text { Frequency } \\
(\mathrm{Hz})\end{array}$ & $\begin{array}{c}\text { 7-day LFC } \\
\text {-CTR }\end{array}$ & $\begin{array}{c}\text { 7-day LFC } \\
\text {-ES5.0 }\end{array}$ & $\begin{array}{c}\text { 28-day LFC } \\
\text {-CTR }\end{array}$ & $\begin{array}{c}\text { 28-day LFC } \\
\text {-ES5.0 }\end{array}$ & $\begin{array}{c}\text { 56-day LFC } \\
\text {-CTR }\end{array}$ & $\begin{array}{c}\text { 56-day LFC } \\
\text {-ES5.0 }\end{array}$ & $\begin{array}{c}\text { 90-day LFC } \\
\text {-CTR }\end{array}$ & $\begin{array}{c}\text { 90-day LFC } \\
\text {-ES5.0 }\end{array}$ \\
\hline 100 & 0.19 & 0.21 & 0.16 & 0.21 & 0.12 & 0.20 & 0.14 & 0.15 \\
125 & 0.15 & 0.21 & 0.17 & 0.20 & 0.17 & 0.20 & 0.18 & 0.20 \\
160 & 0.19 & 0.19 & 0.18 & 0.19 & 0.18 & 0.21 & 0.15 & 0.17 \\
200 & 0.18 & 0.23 & 0.17 & 0.20 & 0.17 & 0.19 & 0.15 & 0.15 \\
250 & 0.16 & 0.22 & 0.16 & 0.17 & 0.16 & 0.17 & 0.14 & 0.14 \\
315 & 0.16 & 0.15 & 0.15 & 0.16 & 0.15 & 0.15 & 0.12 & 0.14 \\
400 & 0.16 & 0.15 & 0.15 & 0.15 & 0.15 & 0.14 & 0.14 & 0.16 \\
500 & 0.13 & 0.14 & 0.12 & 0.13 & 0.13 & 0.15 & 0.12 & 0.12 \\
630 & 0.14 & 0.15 & 0.11 & 0.14 & 0.11 & 0.13 & 0.09 & 0.12
\end{tabular}




\begin{tabular}{llllllllll}
800 & 0.14 & 0.15 & 0.13 & 0.14 & 0.14 & 0.14 & 0.11 & 0.12 \\
1000 & 0.12 & 0.13 & 0.12 & 0.12 & 0.12 & 0.10 & 0.10 & 0.10 \\
1250 & 0.12 & 0.20 & 0.13 & 0.15 & 0.13 & 0.15 & 0.10 & 0.14 \\
1600 & 0.19 & 0.26 & 0.23 & 0.24 & 0.18 & 0.22 & 0.15 & 0.16 \\
2000 & 0.35 & 0.39 & 0.28 & 0.30 & 0.27 & 0.27 & 0.12 & 0.22 & 0.18 \\
2500 & 0.32 & 0.32 & 0.30 & 0.28 & 0.21 & 0.23 & 0.14 & 0.14 \\
3150 & 0.26 & 0.33 & 0.19 & 0.21 & 0.19 & 0.21 & 0.12 & 0.14 \\
4000 & 0.29 & 0.34 & 0.26 & 0.27 & 0.25 & 0.26 & 0.19 & 0.24 \\
5000 & 0.30 & 0.31 & 0.17 & 0.19 & 0.16 & 0.18 & 0.15 & 0.17 \\
6300 & 0.28 & 0.33 & 0.22 & 0.27 & 0.12 & 0.26 & 0.10 & 0.14 \\
NRC & 0.19 & 0.22 & 0.17 & 0.18 & 0.17 & 0.17 & 0.12 & 0.14 \\
\hline
\end{tabular}

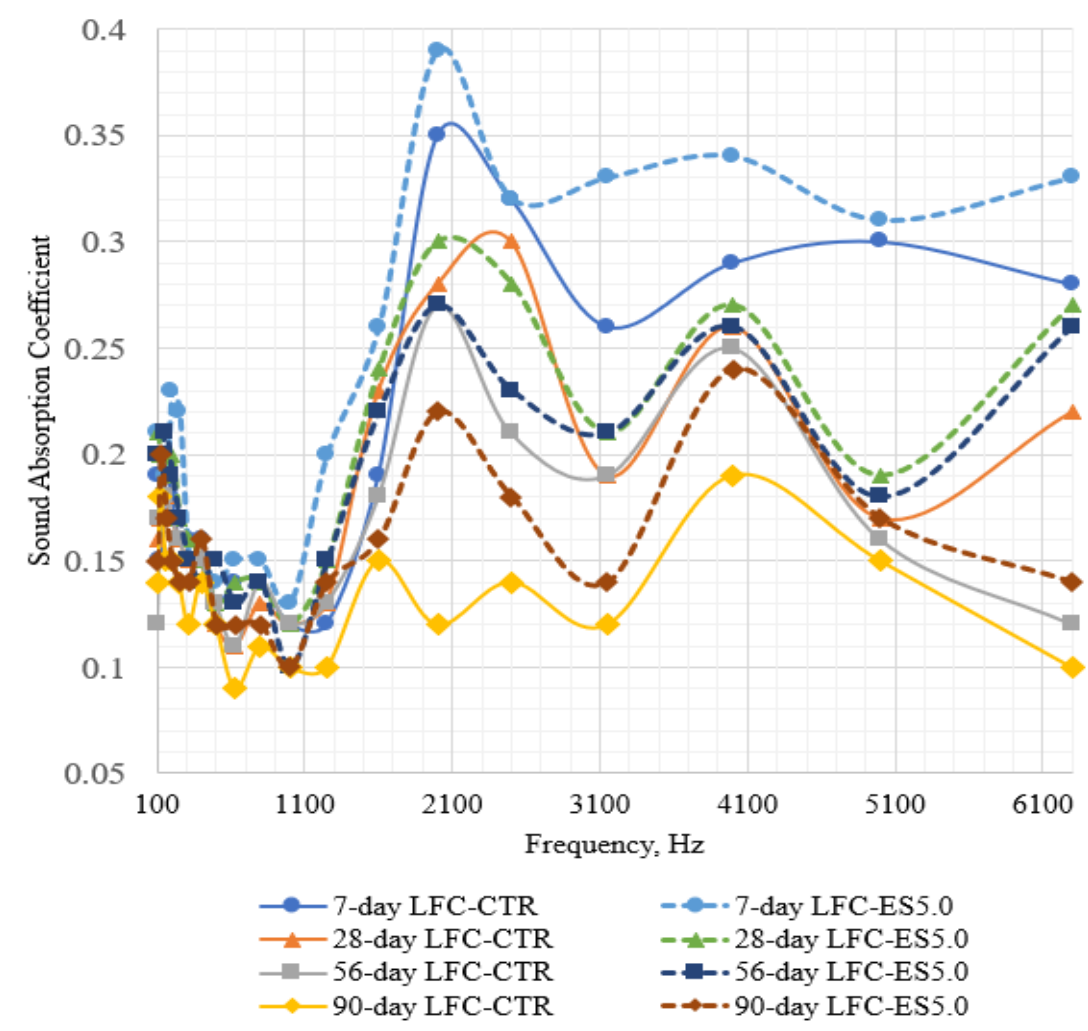

FIGURE 3. Sound absorption coefficients of the lightweight foamed concrete 
For comparison of sound absorption coefficients of LFC-CTR and LFC-ES5.0, it is observable that LFC-ES5.0 has generally higher sound absorption than LFC-CTR at almost all ages and frequencies. For LFC-CTR, the voids are made of cellular voids by entrained air and granular voids (air pockets) by sand particles, calcium hydroxide crystals and C-S-H gels. For LFC-ES5.0, it has one more type of granular void induced by inert amorphous eggshell powder. La Scala Jr. et al. (2000) had studied the porous structure of the studied egg shells, showing that $68 \%$ of the sample pore sizes is between 1.4 and $5.6 \mu \mathrm{m}$, and also presenting photomicrograph for lateral view of eggshell, outer shell pores, and vesicular holes within palisade layer of eggshell. As mentioned by Adams (2016) and Neville
(2011), cellular concrete made of discrete air bubbles has lower sound absorption capability than lightweight aggregate concrete. This is because granular voids induced by lightweight aggregate concrete are more interconnected than cellular concrete to create viscous effect to trap and dissipate sound wave energies.

\section{SOUND TRANSMISSION LOSS}

All sound transmission loss data are tabulated as in Table 5 and Figure 4. They were measured through transfer function method by BSWA VA-Lab4 software as well. Sound transmission class (STC) are also calculated as refer to ASTM E 413 (1999) based on the frequency from 160 to $1600 \mathrm{~Hz}$ and shown in Table 5 .

TABLE 5. Sound transmission loss and sound transmission class (STC) of the lightweight foamed concrete batches (LFC-CTR and LFC-ES5.0) at various ages

\begin{tabular}{|c|c|c|c|c|c|c|c|c|}
\hline $\begin{array}{l}\text { Frequency } \\
(\mathrm{Hz})\end{array}$ & $\begin{array}{c}\text { 7-day LFC } \\
\text {-CTR }\end{array}$ & $\begin{array}{c}\text { 7-day LFC } \\
\text {-ES5.0 }\end{array}$ & $\begin{array}{c}\text { 28-day LFC } \\
\text {-CTR }\end{array}$ & $\begin{array}{l}\text { 28-day LFC } \\
\text {-ES5.0 }\end{array}$ & $\begin{array}{c}\text { 56-day LFC } \\
\text {-CTR }\end{array}$ & $\begin{array}{c}\text { 56-day LFC } \\
\text {-ES5.0 }\end{array}$ & $\begin{array}{c}\text { 90-day LFC } \\
\text {-CTR }\end{array}$ & $\begin{array}{c}\text { 90-day LFC } \\
\text {-ES5.0 }\end{array}$ \\
\hline 100 & 30.3 & 28.5 & 30.5 & 32.2 & 30.6 & 32.5 & 31.9 & 34.1 \\
\hline 125 & 38.7 & 37.7 & 38.9 & 40.4 & 39.3 & 40.7 & 40.9 & 42.6 \\
\hline 160 & 33.1 & 32.0 & 33.4 & 34.5 & 33.6 & 34.8 & 34.8 & 36.4 \\
\hline 200 & 30.0 & 28.8 & 30.2 & 31.2 & 30.4 & 31.5 & 31.5 & 33.0 \\
\hline 250 & 30.0 & 29.9 & 30.0 & 30.6 & 30.4 & 30.6 & 31.1 & 32.1 \\
\hline 315 & 32.1 & 30.9 & 32.4 & 33.2 & 32.6 & 33.5 & 33.5 & 34.6 \\
\hline 400 & 34.1 & 33.2 & 34.4 & 35.0 & 34.6 & 35.3 & 35.4 & 36.3 \\
\hline 500 & 34.0 & 33.3 & 34.2 & 34.8 & 34.5 & 35.2 & 35.1 & 35.9 \\
\hline 630 & 32.1 & 34.0 & 32.9 & 33.2 & 33.3 & 33.5 & 33.6 & 36.5 \\
\hline 800 & 31.7 & 31.3 & 31.9 & 32.3 & 32.1 & 32.7 & 32.7 & 33.8 \\
\hline 1000 & 30.6 & 30.2 & 30.7 & 31.1 & 30.9 & 31.7 & 31.4 & 32.6 \\
\hline 1250 & 28.9 & 28.6 & 29.1 & 29.5 & 29.3 & 30.1 & 29.7 & 30.9 \\
\hline 1600 & 30.4 & 30.3 & 30.4 & 31.0 & 30.5 & 31.9 & 30.6 & 31.9 \\
\hline 2000 & 21.0 & 20.3 & 21.1 & 21.6 & 21.2 & 22.2 & 21.6 & 22.4 \\
\hline 2500 & 12.5 & 11.8 & 12.8 & 13.3 & 12.9 & 13.7 & 13.3 & 14.1 \\
\hline STC & 32 & 32 & 33 & 33 & 33 & 34 & 33 & 34 \\
\hline
\end{tabular}

The STC is calculated based on the frequency from 160 to $1600 \mathrm{~Hz}$ 


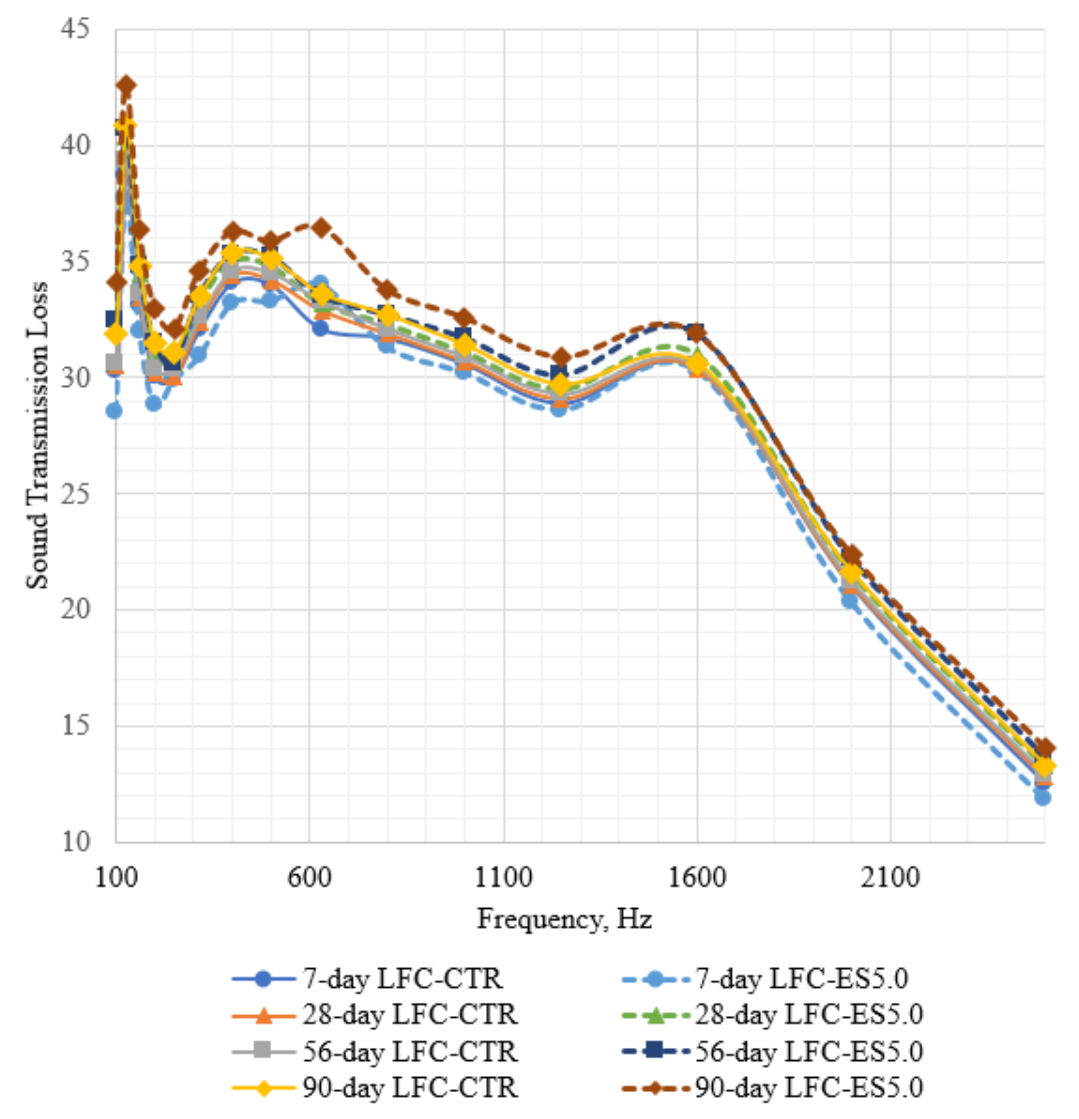

FIGURE 4. Sound transmission losses of the lightweight foamed concrete

Referring to the results, the sound transmission class for the LFCs are around STC-33 as refer to ASTM E 413 (1999). By comparing the sound transmission losses at the third octave bands, the sound transmission losses of the LFC at later age are generally higher than their early age. It is relevant as the samples are stiffer as they are gaining higher strength from cement or pozzolanic reaction when curing periods increase. Therefore, the samples can have higher sound transmission losses at longer curing periods or higher strengths as they are 'denser' in the sense that air voids and capillary pores are greatly reduced, filled with hydrated cement pastes that have greater masses to restraint sound wave energies.

It is observed that sound transmission losses of LFC-ES5.0 are generally higher than LFC-CTR. It might because LFC-ES5.0 has extra pozzolanic that might improve performance strengths of LFC-ES5.0 cube samples by producing more C-S-H pastes, and also meanwhile incorporating calcite partly into C-S-H pastes being precipitated. Therefore, LFC-ES5.0 has stiffer and stronger developed C-S-H skeleton to restraint and block sound wave energies. In addition, calcium carbonate from eggshell might reduce the sound velocity (Garlan et al. 2015) and hence LFC-ES5.0 has improved sound transmission property. It is also observable that the sound transmission loss difference of both LFC is getting higher when curing periods increase. Despite, there is an exception at the age of 7-day that sound transmission loss of LFCES5.0 is lower than LFC-CTR. This might be due to the lower 7-day compressive strength of LFC-ES5.0 specimen as compared to LFC-CTR, in another word, it is weaker to restraint and block sound wave energies. The computed STC for the LFC at later age also are generally higher than their early age as well.

\section{CONCLUSION}

Some conclusions can be drawn based on the study: Five percent eggshell powder as cement replacement material in lightweight foamed concrete reduced the initial strength. At optimal mix proportion, five percent eggshell powder as cement replacement material in lightweight 
foamed concrete enhanced the 28-day strength compared to that of the control mix. Five percent eggshell powder can improve sound absorption and sound transmission loss of $1300 \mathrm{~kg} \mathrm{~m}^{-3}$ lightweight foamed concrete in general. Eggshell mixture generally has higher noise reduction coefficient in the frequency range from 100 to $6300 \mathrm{~Hz}$ compared to that of control mixture. The sound transmission class for the both lightweight foamed concrete mixtures are around STC-33 in the frequency range from 160 to $1600 \mathrm{~Hz}$.

\section{ACKNOWLEDGEMENTS}

The support provided by Universiti Tunku Abdul Rahman (UTAR) for this study are very much appreciated.

\section{REFERENCES}

Adams, T. 2016. Sound Materials: A Compendium of Sound Absorbing Materials for Architecture Design. Amsterdam: Frame Publishers. pp. 1-286.

American Society for Testing and Materials. 1999. ASTM E 413 - 87: Classification for Rating Sound Insulation. United States: ASTM International. pp. 1-4.

Aprianti, S.E. 2017. A huge number of artificial waste material can be supplementary cementitious material (SCM) for concrete production - A review part II. Journal of Cleaner Production 14: 4178-4194.

Ayodeji, A.A., Modupe, O.E., Rasheed, B. \& Ayodele, J.M. 2018. Data on $\mathrm{CaO}$ and eggshell catalysts used for biodiesel production. Data in Brief 19: 1466-1473.

British Standards Institution. 2002. BS EN 12390 - 3: Testing Hardened Concrete - Part 3: Compressive Strength of Test Specimens. London: British Standards Institution. pp. 1-7.

Egab, L., Wang, X. \& Fard, M. 2014. Acoustical characterisation of porous sound absorbing materials: A review. International Journal of Vehicle Noise and Vibration 10(12): $129-149$.

Garlan, T., Köng, E., Guyomard, P., Mathias, X. \& Zaragosi, S. 2015. The sedimentary and acoustic properties of deep sediments from different oceans. In Proceedings of the Institute of Acoustics 37(1): 1-10.

Juenger, M.C.G. \& Siddique, R. 2015. Recent advances in understanding the role of supplementary cementitious materials in concrete. Cement and Concrete Research 78: 71-80.

La Scala Jr., N., Boleli, I.C., Ribeiro, L.T., Freitas, D. \& Macari, M. 2000. Pore size distribution in chicken eggs as determined by mercury porosimetry. Brazilian Journal of Poultry Science 2(2): 177-181.

Lim, S.K., Tan, C.S., Lim, O.Y. \& Lee, Y.L. 2013. Fresh and hardened properties of lightweight foamed concrete with palm oil fuel ash as filler. Construction and Building Materials 46: 39-47.

Lu, T., Chen, F. \& He, D. 2000. Sound absorption of cellular metals with semi open cells. The Journal of the Acoustical Society of America 108(4): 1697-1709.
Manzur, T., Shams Huq, R., Hasan Efaz, I., Afroz, S., Rahman, F. \& Hossain, K. 2019. Performance enhancement of brick aggregate concrete using microbiologically induced calcite precipitation. Case Studies in Construction Materials 11: e00248.

Matschei, T., Lothenbach, B. \& Glasser, F.P. 2007. The role of calcium carbonate in cement hydration. Cement and Concrete Research 37(4): 551-558.

Mehta, P.K. 1977. Properties of blended cements made from rice-husk ash. In Journal Proceedings 74(9): 440-442.

Neville, A.M. 2011. Properties of Concrete. 5th ed. Harlow: Pearson Education Ltd. pp. 1-872.

Ramamurthy, K., Kunhanandan Nambiar, E. \& Indu Siva Ranjani, G. 2009. A classification of studies on properties of foam concrete. Cement and Concrete Composites 31(6): 388-396.

Ramezanianpour, A.M. \& Hooton, R.D. 2014. A study on hydration, compressive strength, and porosity of Portlandlimestone cement mixes containing SCMs. Cement and Concrete Composites 51: 1-13.

Shafigh, P., Mahmuda, H., Jumaat, M.Z. \& Zargar, M. 2014. Agricultural wastes as aggregate in concrete mixtures-A review. Construction and Building Materials 53: 110-117.

Sonenklar, C. 1999. Famous for egg waste. Penn State News. [online] News.psu.edu. https://news.psu.edu/ story/140891/1999/09/01/research/famous-egg-waste. Accessed on 24 July 2020.

Tangchirapat, W., Saeting, T., Jaturapitakkul, C., Kiattikomol, K. \& Siripanichgorn, A. 2007. Use of waste ash from palm oil industry in concrete. Waste Management 27(1): 81-88.

Tchuente, F.M., Tchakouté, H.K., Banenzoué, C., Rüscher, C.H., Kamseu, E., Andreola, F. \& Leonelli, C. 2019. Microstructural and mechanical properties of $(\mathrm{Ca}, \mathrm{Na})$ poly(sialatesiloxo) from metakaolin as aluminosilicate and calcium silicate from precipitated silica and calcined chicken eggshell. Construction and Building Materials 201: 662-675.

Tiong, H.Y., Lim, S.K., Lee, Y.L., Ong, C.F. \& Yew, M.K. 2020. Environmental impact and quality assessment of using eggshell powder incorporated in lightweight foamed concrete. Construction and Building Materials 244: 118341.

Tiong, H.Y., Lim, S.K. \& Lim, J.H. 2017. Strengths and sorptivity of lightweight foamed concrete with crushed steel slag. Journal of Built Environment, Technology and Engineering 3: $37-48$.

Tito, J.A., Hernandez, L. \& Trujillo, J. 2010. Use of high strength lightweight concrete to construct a postensioned segmental beam. In 8th Latin American and Caribbean Conference for Engineering and Technology LACCEI. pp. 1-9.

Udoeyo, F.F. \& Dashibil, P.U. 2002. Sawdust ash as concrete material. ASCE Journal of Materials in Civil Engineering 14(2): 173-176.

Virdi, S. 2012. Construction Science and Materials. New York: Willey-Blackwell. pp. 1-352.

Zhao, X., Lim, S.K., Tan, C.S., Li, B., Ling, T.C., Huang, R. \& Wang, Q. 2015. Properties of foamed mortar prepared with granulated blast-furnace slag. Materials 8(2): 462-473. 
Lim Siong Kang*, Foo Kar Poh, Lee Foo Wei, Tiong Hock Yong, Lee Yee Ling \& Lim Jee Hock

Department of Civil Engineering

Universiti Tunku Abdul Rahman

Jalan Sungai Long, Bandar Sungai Long

Cheras 43000 Kajang, Selangor Darul Ehsan

Malaysia
King Yeong Jin

Department of Mechanical and Materials Engineering Universiti Tunku Abdul Rahman

Jalan Sungai Long, Bandar Sungai Long

Cheras 43000 Kajang, Selangor Darul Ehsan

Malaysia

*Corresponding author; email: sklim@utar.edu.my

Received: 15 June 2020

Accepted: 27 July 2020 